MAGDALENA DZIURZYŃSKA

University of Wrockaw, Poland

e-mail: magdalena.dziurzynska2@uwr.edu.pl

\title{
"Hope as the Engine for Imagining Utopia": A Dream of a World Beyond Gender
}

\begin{abstract}
By analyzing the depiction of androgyny in Marge Piercy's science fiction novels in the context of gender performativity and constructionism, this article demonstrates that androgyny may be used as a tool for deconstructing gender roles. Arguably, Piercy proposes a new, non-essentialist vision of humankind through the creation of androgynous or agender human and cybernetic bodies. Moreover, the article substantiates how the images of utopian worlds, which present futuristic hope, are connected with the postgender idea of gender transcendence, while the dystopian ones seem to be strongly related to gender essentialism.
\end{abstract}

Keywords: gender, androgyny, postgenderism, science fiction, Marge Piercy, utopia, dystopia, hope

„Utopia jako nadzieja”: w stronę świata poza granicami płci

Streszczenie: Poprzez analizę przedstawienia androginii w powieściach science fiction autorstwa Marge Piercy w kontekście performatywności płci i konstrukcjonizmu niniejszy artykuł pokazuje, że androginia może być wykorzystywana jako narzędzie dekonstrukcji ról płciowych. Piercy proponuje nową, nie esencjonalistyczną wizję ludzkości poprzez tworzenie androgynicznych lub agenderowych ludzkich i cybernetycznych ciał. Ponadto artykuł ukazuje, w jaki sposób obrazy utopijnych światów, które niosą z sobą futurystyczną nadzieję, wiążą się z postgenderową ideą transcendencji płci, podczas gdy dystopijne światy wydają się silnie powiązane $\mathrm{z}$ esencjalizmem płciowym.

Słowa kluczowe: płeć kulturowa, androgynia, postgenderyzm, fantastyka naukowa, Marge Piercy, utopia, dystopia, nadzieja

Many authors choose to effectively challenge the concept of gender by creating fictional worlds which question or criticize gender assumptions that exist in their own cultures. The genre of science fiction serves as a ground for such representations, as it very often describes worlds in which the perception of reality is altered and put into an unknown, fictional context. According to Brian Attebery, "science 
fiction is a useful tool for investigating habits of thought, including conceptions of gender. Gender, in turn, offers an interesting glimpse into some of the unacknowledged messages that permeate science fiction." ${ }^{\prime \prime}$ Science fiction also makes it possible to extend the idea of gender, incorporating transgender, nonhumans, alien or cybernetic individuals. Such representations provide insight into the construction of gender, at the same time, making it possible to reverse or deconstruct this concept.

Numerous variations and expressions of masculinity and femininity may serve to subvert the gender and sex dichotomy. Moreover, many science fiction works include utopian or dystopian spaces, which depict gender in a particular - desirable or undesirable - context. While dystopia is usually perceived as a nightmarish image of the extreme consequences of particular social or political factors, utopias incorporate the futuristic portrayal of better, improved worlds. The fundamental aim of the utopia is not, however, to fantasize about the future but to criticize the present and to offer alternative futuristic models, proposing some changes which may be implemented for further development. Consequently, the comparison of the real world and the imaginary one helps to express such a critique and to present hope for the possibility of a better future.

Within the genre of utopia, feminist utopias were particularly involved withtransforming existing sexual practices or beliefs concerning gender and gender stereotypes. Since feminist utopias went "beyond the phallocratic paradigm," they were capable of introducing worlds in which traditional patriarchal models are deconstructed. The concept of gender is very often put into question on account of gender being a social construct. Attebery identifies a variety of techniques in which the category of gender is challenged or deconstructed in speculative literature. Among the most prominent examples are alternative societies composed of one sex only (Herland, The Female Man), cybernetic spaces with gendered androids (He, She and It), or transgender worlds (A Civil Campaign). However, some authors like Octavia E. Butler, Marge Piercy, or Ursula K. Le Guin, decide to go beyond gender polarization, proposing androgynous worlds, in which gender is either ambiguous or ceases to exist.

Pamela J. Annas suggests defining androgyny on two levels. The first one, she claims, is psychological and sociological, and it refers to general androgynous personality. ${ }^{3}$ In this regard, androgyny is perceived by means of some culturally defined sex-appropriate preferences, skills, personal traits, behaviors, and perceptions of oneself. The other level is what she calls "the androgynous moment" which is perceived as a "psychic unity, either potential or actual." ${ }^{4}$ She also draws attention to the fact that historically androgyny has been viewed as "the mystical

${ }^{1}$ B. Attebery, Decoding Gender in Science Fiction, New York 2002, p. 1.

2 T. Teslenko, Feminist Utopian Novels of the 1970s: Joanna Russ and Dorothy Bryant, New York 2003, p. 35.

${ }^{3}$ P. Annas, New Worlds, New Words: Androgyny in Feminist Science Fiction, "Science Fiction Studies" 1978, 15.5/2, Jul., p. 146-147.

${ }^{4}$ Ibid. 
moment or a sense of oneness with God." ${ }^{5}$ Androgyny is thus defined as the idea of oneness, completeness and unification of polarities as harmonized wholeness.

Apart from the psychological aspect, androgyny is also defined in reference to the stylization of the body, which implies the general appearance and clothing attributed to either sex. Furthermore, Judith Halberstam argues that androgyny is, in fact, "figured as the perfect blend of the masculine and the feminine and the creation of gender harmony." "It could thus be presumedthat androgyny is the expression of gender fluidity. Androgynous bodies are not limited to the opposite ends of the spectrum of masculinity and femininity, but instead they possess both at once, in various combinations. As opposed to gender dualism, androgyny may, in many ways, combine different characteristics which are said to be either feminine or masculine, and therefore it is not a stable category. Tracy Hargreaves defines androgyny as: "(...) the embodiment of an identity defined through usually same-sex sexual orientation and/or cross-gender identification, an emblem (or fantasy) of a behavior where positive traits, identified as masculine and feminine, work harmoniously in a single individual." Accordingly, it is a kind of unity or reconciliation of the expression of two sexes, which creates gender ambiguous individuals. It may be therefore arguedthat androgyny is the deconstruction of traditional gender polarization, as it proposes new "cross-gender" units, which do not stand in opposition to one another, but rather interpenetrate.

The two discussed concepts, androgyny and utopia, serve as a ground not only for a discussion of gender but also for social criticism and polemics with the assumptions of gender essentialism. As Elisabeth Grosz in her analysis of gender essentialism points out: "women's essence is assumed to be given and universal and is usually (...) identified with women's biology and 'natural' characteristics." 8 She further adds that these are not only biological features, but also psychological characteristics that are stereotypically believed to be attributed to women's essence. ${ }^{9}$ Hence, in terms of biologism, essentialism is based on the assumptions that social and cultural factors arise from biological and psychological traits of either women or men. On the basis of these "fixed" and "intrinsic" qualities, femininity and masculinity are determined and in turn serve as the ground for the dualistic and gender-hierarchical structure of society.

In opposition to essentialist views, some feminist writers use androgyny as a postgender model, or vision, of what is desired, since it necessitates abandoning stereotypical assumptions about gender roles. Attebery points out that for some feminist writers androgyny is "a desirable goal and an unacknowledged reality." He further explains that "a society that learned to recognize and encourage fluid

\footnotetext{
5 Ibid.

6 J. Halberstam, Female Masculinity, London 1998, p. 215.

7 T. Hargreaves, Androgyny in Modern Literature, New York 2005, p. 3.

8 E. Grosz, Space, Time and Perversion: Essays on the Politics of Bodies, New York 1995, p. 48.

9 Ibid.

10 B. Attebery, op. cit., p. 130.
} 
gender identities would be one in which lives would be more satisfying and psyches more integrated." 11

As one of the concerns of feminist utopias was to deconstruct the traditional interpretation of gender binarism; ${ }^{12}$ in this regard, the concept of androgyny may be regarded as an endeavour to depart from gender dualism in favour of a universalisation of general human traits. The creation of gender ambiguous individuals helps to challenge the constructed gender dichotomy and such an image is placed in the utopian context of futuristic hope. Such portrayals acknowledge that behaviors and traits have no gender, which emphasizes the importance of the individual potential of human being. Among the best-known works incorporating the concept of androgyny are, for instance, The Left Hand of Darkness by Ursula K. Le Guin, Orlando by Virginia Woolf, Venus Plus X by Theodore Sturgeon or Woman on the Edge of Time and He, She and It by Marge Piercy, with the last two being the main concern for this paper.

Both Woman on the Edge of Time (1976) and He, She and It (1991) contain similar ideas, although they were published fifteen years apart. The two novels revolve around the female heroines who learn to recognise their inferior social position and to fight against patriarchal oppression. Both works are classified as science fiction, but at the same time they introduce utopian and dystopian spaces as well, through which the author acknowledges enticing or loathsome visions of the possible future. One of the main objectives of the novels is to challenge contemporary gender roles and examine futuristic possibilities of gender neutrality.

Piercy employs the concept of androgyny to raise the question of the traditional gender dichotomy, at the same time juxtaposing rigid gender roles with a desirable future beyond gender binaries. While Woman on the Edge of Time incorporates an androgynous genderless society, He, She and It encompasses vivid androgynous characters. At this point, it is also important to mark a difference between these two concepts. While androgyny is mostly related to the physical interpretation of a subject, concerning both body and personal attributes; genderlessness should be understood as one's own identity and internal sense out of the binary.

Both androgyny and genderlessness, incorporated in Piercy's novels, combine the exploration of masculinity and femininity, which occurs through interactions of the protagonists and the descriptions of the social models. Piercy, in fact, challenges the entire concept of gender polarisation, pointing to the social construction of gender. She considers a variety of characteristics in the context of general human traits, at the same time proposing the extolment of gender neutrality.

The main protagonist of Woman on The Edge of Time is Connie Ramos an ethnic female who finds herself in the patriarchal New York of the 1970s, where she suffers from oppression on many levels including her gender, race and age. She is confined to a mental institution due to her supposed violent tendencies. While being there, she is visited by the mysterious individual Luciente, who

11 Ibid.

12 A. Johns, Feminism and Utopianism [in:] The Cambridge Companion to Utopian Literature, ed. G. Claeys, Cambridge 2010, p. 183. 
claims to be a visitor from the future. Connie is taken by Luciente to the city of Mattapoisett in the year 2137. Connie is incessantly astonished by Luciente's ambiguous appearance and demeanor. She believes the visitor to be an effeminate gay man as, according to her, Luciente behaves in a feminine way but possesses a masculine appearance. Only when Connie closely approaches Luciente does she become aware of the fact that she is a female, as she can distinguish her breasts. Thenceforth, Connie's perception changes, and she begins to see Luciente as a woman: "Now she could begin to see him/her as a woman. Smooth hairless cheeks, shoulder-length thick black hair. You're well-muscled for a woman."13 Hereby, Piercy shows how the perception of a person changes when their gender is assigned according to stereotypical beliefs. Connie perceives gender and sex from the point of view of her polarized society; thus, she is trapped in distinguishing one's sex on the basis of social stereotypes. Such a phenomenon was addressed by Judith Butler who called it the "illusory appearance": "If one thinks that one sees a man dressed as a woman or a woman dressed as a man, then one takes the first term of each of those perceptions as the 'reality' of gender: the gender that is introduced through the simile lacks 'reality,' and is taken to constitute an illusory appearance." $" 14$

The other androgynous characters are also presented through Connie's dualistic gender perception; therefore, the description that she provides classifies the traits of those individuals as either feminine or masculine. The combination or even blurring of those characteristics in the androgynous inhabitants of Mattapoisett confuses Connie. When she encounters Bee, who she knows to be a biological male, she is disoriented seeing him in a long robe. Bee, who in the eyes of Connie, is a well-built, muscled black man, who stereotypically should be heartless and tough, turns out to be a caring and sensitive person who weeps, gets emotional and takes care of newborn babies. The mixture of stereotypical, physical masculine traits with feminine nurturing abilities makes it hard for Connie to classify Bee into any gender category. Another interesting individual is a tall, thin and strong male called Jackrabbit, who despite his masculine appearance reveals nurturing and caring behaviors. Jackrabbit is also described as a mother, who at the same time joins the military service.

This phenomenon of gendering and gender confusion was also discussed by Judith Butler, who explains: "when one cannot with surety read the body that one sees, is precisely the moment when one is no longer sure whether the body encountered is that of a man or a woman. The vacillation between the categories itself constitutes the experience of the body in question." ${ }^{15}$ The androgynous bodies are undermined by Connie, as such non-gendered stylization of these bodies seems to go beyond her dichotomous perception. Still, androgynous utopia achieves a perfect balance of personality attributes traditionally considered masculine or feminine, through the deconstruction of gender binary opposites. Going beyond strict gender/sex categories creates such an equilibrium, in which people

\footnotetext{
${ }_{13}$ M. Piercy, Woman on the Edge of Time, New York 1976, p. 67-68.

${ }_{14}$ J. Butler, Gender Trouble, New York 1990, p. xxii.

15 Ibid., p. xxi.
} 
are not gendered and classified, but instead, the society is based on personal capabilities and individual specificity. Even though Connie attempts to categorize androgynous individuals as male or female, they see each other merely as 'people,' who, in our dualistic perception, may have masculine or feminine traits in many varieties, according to the role they are fulfilling in the society. Such a state, of having two roles assigned, is possible also due to the fact that children in the utopia do not undergo the process of gender-based socialization. As Luciente speaks about Connie's world, she observes that: "They [people in Connie's world] had many toys for teaching sex roles to children." 16 For this reason, the upbringing in the utopia transcends stereotypical gender performative acts, as children are taught all the skills from which they can choose what pleases them most.

In her genderless utopia Piercy eradicates yet another dichotomy, which may traditionally be encountered in normative heterosexuality. As Alison Jaggar points out, Piercy opts for “(...) a situation in which the sex of one's lover is a matter of social indifference, so that the dualist categories of heterosexual, homosexual and bisexual may be abandoned." 17 Indeed, the idea of fixed sexuality does not exist in the utopia since any persons can 'couple' and there are no notions of heterosexuality or non-heterosexuality for those genderless subjects. The genderneutral society replaces the binary one, introducing the acceptance of variety and individual preferences.

Woman on the Edge of Time also broadens the concept of genderlessness by incorporating gender neutrality into the language. Therefore, apart from physical androgyny, the notion of genderlessness is also incorporated in the discourse. The language of Mattapoisett goes beyond gender binary, and consequently, aligns itself with the androgyny of inhabitants, as the masculine and feminine pronouns are abandoned. Instead, in the utopia, the pronouns used are "per" - the abbreviation of "person" - to allow gender neutral communication: "Magdalena has no family. Person wants this instead. Person is chaste and solitary among adults;" 18 "Barbarossa dyes per beard, in truth." 19 This experiment with language is an imperative when attempting to portray a genderless world. The new form of language proposed in the utopian world provides androgynous individuals with the possibility of becoming the absolute subject outside biased, gendered discourse. Therefore, as absolute subjects they can exist in the discourse as independent, neutral entities who are not embedded in gendered language structures.

Piercy creates a society in which not only the concept of gender disappears, but the role of biological sex is limited to a minimum. Even though the biological distinctions between males and females remain, they are neutralized. Many feminist writers tried to achieve an egalitarian society by deconstructing the cultural concept of gender, for example, by creating gender fluid or single-sex societies. Piercy goes even further and creates a society of total gender equality by not only rejecting the idea of gender, but also by dismissing biological roles.

\footnotetext{
${ }^{16}$ M. Piercy, Woman on the Edge..., op. cit., p. 147.

${ }_{17}$ A. Jaggar, Feminist Politics and Human Nature, Sussex 1983, p. 132.

${ }^{18}$ M. Piercy, Woman on the Edge ..., op. cit., p. 146.

19 Ibid., p. 106.
} 
She proposes separating sexuality from reproduction in order to eliminate the role of biological sex, and to achieve this she suggests a technology - more precisely, ectogenesis, defined by Gelfand as the "development of an embryo in an artificial environment." ${ }_{20}$ It is a procedure in which embryos are developed in specially designed artificial wombs, outside women's bodies. Such ideas were already proposed by the early science fiction writers (for example, by Aldous Huxley in Brave New World in 1932) and were widely developed in the 1970s by feminists who saw the roots of oppressive power in childbearing. Six years before Piercy's novel was published, Shulamith Firestone, in her The Dialectic of Sex, expressed her views about the oppressive power of childbearing. She claims that: "The heart of woman's oppression is her childbearing and childbearing roles." ${ }^{21}$ It was believed that woman's reproductive biology accounted for her continued oppression. As women were constantly during pregnancy and nursing, they became financially dependent on men and were excluded from social functions.

The solutions proposed by Firestone find continuation in postgender theories. Dvorsky and Hughes draw attention to the fact that the biological foundations of gender dualism determine and limit the human condition. ${ }^{22}$ They also see the possibility of overthrowing those gender differences by minimalizing or even blurring the role of biological sex with the use of technology: "(...) only the blurring and erosion of biological sex, of the gendering of the brain, and of binary social roles by emerging technologies will enable individuals to access all human potentials and experiences regardless of their born sex or assumed gender." ${ }^{23}$ Therefore, it is argued that the liberation of full human potential, and the means to achieve equality, may be reached through the introduction of a genderless society, in which the importance of biological sex is minimalized or even eradicated. Dvorsky and Hughes also refer to the idea incorporated in Haraways' Cyborg Manifesto, in which she claims that technology and integration of humans and machines might lead to the creation of "new liberatory androgynous archetype," which can be the way to "find liberation from patriarchy." 24 Consequently, in order to fundamentally diminish both patriarchy and gender, women should be freed from childbearing with the use of technology and artificial wombs. In such a way, the androgynous bodies, who are determined neither by gender nor by their sex, may exist in equality, with no gender constraints.

The same issue is taken up by Alison Jaggar who also views androgyny as a possible mean for the deconstruction of gender dichotomy in favor of gender neutrality. She further proposes that it needs to go beyond "psychological an-

20 S. Gelfand, J. Shook, Ectogenesis: Artificial Womb Technology and the Future of Human Reproduction, New York 2006, p. 1.

21 S. Firestone, The Dialectic of Sex: The Case for Feminist Revolution, New York 1970, p. 72.

22 G. Dvorsky, J. Hughes, Postgenderism: Beyond the Gender Binary [in:] IEET Monograph Series, Boston 2008, p. 2.

23 Ibid., p. 3.

24 D. Haraway, A Cyborg Manifesto: Science, Technology, and Socialist-Feminism in the Late Twentieth Century [in:] Simians, Cyborgs, and Women: The Reinvention of Nature, New York 1991, p. 155. 
drogyny" covering also "physical human capacities." ${ }^{25}$ She additionally suggests the idea of "overcoming women's alienationt hrough the elimination of labor." 26 In this utopian future, reproduction takes place outside women's bodies; thus, women are no longer constrained by childbearing and pregnancy. Piercy gives women this freedom, pointing out that in order to introduce the equalitarian society, with no gender roles imposed, it was necessary to give up biological reproduction: "It was part of women's long revolution. When we were breaking the old hierarchies. Finally, there was that one thing we had to give up too (...). The original production: the power to give birth. Cause as long as we were biologically enchained, we'd never be equal." ${ }^{27}$ Thereupon, it was childbearing and motherhood that needed to be given up to have power of any kind. In Mattapoisett not only does reproduction occur outside females' bodies, but there are also three parents, each of whom is taking care of nursing. By eliminating natural reproduction, Piercy constructs a society in which both sexes take an active part in children's upbringing, including breastfeeding, which is hormonally assured for both males and females. Thanks to such a solution, gender equality could be achieved and both parents have a biological relationship with their children, thereby eliminating the biological determining of gender power.

Moreover, as was previously proposed by Jaggar, biological sex does not determine sexual relationships of the inhabitants of Mattapoisett. They "couple not for money, not for a living. For love, pleasure, for relief, out of habit, out of curiosity" 28 and are involved in sexual intercourse with whoever they want, not paying attention to their biological sex. There is visible hope for an egalitarian society, general gender equality and the wish for the world in which people are allowed to be whoever they want without being restrained by assigned gender roles. Therefore, the existence of an equal, postgender world requires the eradication not only of the concept of gender, but also the impact of biological sex. The combination of psychological and physical androgyny may help to create genderless and sex neutral bodies who do not have power over one another. To go beyond gender binarism, it is indispensable to contravene the heterosexual matrix, which Butler defines as "a model of gender intelligibility that assumes that for bodies to cohere and make sense there must be a stable sex expressed through a stable gender (masculine expresses male, feminine expresses female) that is oppositionally and hierarchically defined through the compulsory practice of heterosexuality." ${ }^{29}$ The transgression of the boundaries of biological sex and traditional gender expression means that the assumption about biological sex being precursive has to be rejected. Accordingly, to exist outside of a hegemonic heterosexual matrix, one must confront social constructionism and turn towards gender transcendence, which may be achieved by minimalizing the role of biological sex, for instance, by technological means.

\footnotetext{
${ }^{25}$ A. Jaggar, op. cit., p. 132.

${ }^{26}$ Ibid.

${ }^{27}$ M. Piercy, Woman on the Edge..., op. cit., p. 112.

${ }^{28}$ Ibid., p. 66.

29 J. Butler, op. cit., p. 194.
} 
The idea of social constructionism in relation to gender means that "[p]eople called 'females' or 'males' are endowed with certain traits defined as feminine or masculine. Concepts such as gender, therefore, must be found in the meanings people bring to them." 30 Therefore, gender is perceived not as an inner attribute, but rather as a status which is achieved in a social environment, in interactions with others. As individuals are categorized as either male or female, they are perceived through their gender which at the same time imposes on them some specific social behaviors. Thus, the concept of gender, which is used to collectively categorize people, emerges through a socially constructed process, which in this case must be confronted to achieve the possibility of eradicating gender and sex binaries.

With the rejection of social constructionism, it is possible to turn towards eradication of gender dichotomy and consequently, gender transcendence. In general terms, transcendence can be understood as extending or lying beyond the usual limits or beyond the boundaries. Furthermore, transcendence may also be referred to the identity of an individual. In that case, what emerges is the concept of selftranscendence, which means the rejection of the socially defined limits of individual identity. Hence, gender transcendence can be perceived as going beyond the limits of gender binary in favour of gender naturality and fluid gender identity. As Garnets and Pleck suggest, gender transcendence is "a stage in which masculinity and femininity are 'transcended' as ways of organizing and experiencing psychological traits. (...) For sex role transcendent individuals, there is no relationship between having or not having sex role related traits and psychological adjustment." 31 Therefore, in individual development, transcendence is seen as a possibility for oneself not to be reduced to a gender role, but to become an agent defined by general human traits. That idea of transcendence could in turn be achieved by eroding the binary division of gender, allowing for gender neutrality. In the utopian city that Piercy portrays, gender transcendence is accomplished not only by rejection of social constructivism, but also by this turn towards gender transcendence, which was enabled by the eradication of both gender dichotomy and the impact of biological sex.

In He, She and It, Piercy takes androgyny on to the next level, which is cyborg imagery. Once again, she expresses androgyny in various degrees to deconstruct the stereotypical gender notions of masculinity and femininity. Those androgynous bodies are also mostly connected to the utopian world, which in the case of $H e$, She and It, is the place called Tikva, which itself signifies hope in Hebrew. Tikva is a libertarian and democratic utopia where males and females are equal, as there are no hierarchy or gender roles on any level. The basis of the society is grounded in cooperation and joint work for the benefit of the city. The concept of gender is presented as fluid, and everyone, especially children, are free to reach any goals in their lives regardless of their sex or gender. Sexuality, just as gender,

${ }^{30}$ L.L. Lindsey, The Sociology of Gender [in:] Gender Roles: A Sociological Perspective, Boston 2015, p. 10.

${ }^{31}$ L. Garnets, J.H. Pleck, Sex Role Identity, Androgyny, and Sex Role Transcendence, "Psychology of Women Quarterly" 1979, 3(3), p. 273-274. 
is also fluid and all kinds of intimate contacts and relationships are accepted, with homosexuality being even expected.

The protagonist, Shira, comes from the dystopian city of Y-S and at the beginning seems to personify a stereotypical construction of a woman oppressed by social structures and constructivism. However, as in the case of Connie, in the course of the novel she changes and becomes, to some extent, an androgynous individual. She becomes the one who shares both physical and psychological traits normally attributed to both men and women, which in some ways illustrates the concept that gender is not intrinsic and may be fluid. She is influenced by other androgynous characters who she meets throughout the novel. As in the case of Woman on the Edge of Time, here the perception of other individuals is introduced mostly through the eyes of Shira. This time, however, the main protagonist is not only confused by androgynous bodies but impressed by their qualities, selfacceptance and joviality.

Shira's close friend is Gadi with whom she reunites in Tikva after many years. Gadi is an ambiguous male character who is described as possessing mostly feminine traits, both physically and psychologically. He has "dyed skin and hair" and wears "tunic flitted with shape leaves and high-heeled emerald shoes." ${ }^{32}$ At the same time, he is described as a stereotypical tough macho, who manifests assertive domination and pride in his masculinity, connected with aggressive sexual drive. Hence, in spite of his rather feminine appearance, he is markedly masculine, which makes him rather gender ambiguous.

The other three strongly androgynous characters are females. Riva, Shira's mother, who is openly lesbian and admits to having had plenty female lovers, is described as a well-built fighter with very short hair. She has an analytical and logical mind, stereotypically attributed to men and, what is more, she has hardly any "feminine" traits but is described as the masculine female. A similar example of androgynous individual is Malkah, a woman, who shares nurturing and caring traits in addition to rationalism and intellectualism. Moreover, she is sexually liberated since she admits to having had almost fifty lovers, both female and male, as she confesses that she finds changing her gender enjoyable. Riva's lover Nili is yet another exemplar, and is the most androgynous both in appearance and behaviour. She comes from a female single-sex society, an enclave where women live without any trace of men. Consequently, all the stereotypical gender assumptions are abandoned, as the inhabitants of that society are not familiar with gender dualism at all. Hence, Nili incorporates just those traits that are her personal expressions, or some physical aspects that were essential for her to survive. She is portrayed as a dark-skinned woman, with red hair who is extremely muscular, strong and fit. The most interesting character is, however, the human-made androgynous Cyborg Yod. He is the result of the cooperation between male and female scientists and as a result, in his androgyny, he shares traits attributed to both genders. He manifests male presence with his well-built muscular body, but at the same time his body possesses feminine characteristics such as beautiful soft

\footnotetext{
${ }^{32}$ M. Piercy, He, She and It, New York 1991, p. 384.
} 
hands, smooth face as well as almost no body hair. As regards the psychological aspects, Yod expresses extreme rationality and logical thinking. He is defensive and sometimes aggressive, not even hesitating to kill, if that it is what the situation requires. On the other hand, he is deeply emotional with a lot of personal knowledge, empathy and need for intimacy. As Shira gets involved in the relationship with Yod, she is at times confused and the gender roles in their relationship are very often reversed. Yod is the one who alters Shira's perspective on gender roles and shows her that there is no definition of gender. Thanks to her relationship with a cyborg, Shira understands that there is freedom of choice rather than fixed gender construction. An androgynous cyborg therefore becomes the essential element in the deconstruction of gender dualism. As Haraway proposed: "Cyborg imagery can suggest a way out of the maze of dualisms." ${ }^{33}$ She goes on to claim that cyborgs deconstruct the so-called universal ideas about femininity and masculinity. Since Haraway rejects the separation between machines and humans, she sees them both as socially constructed or reconstructed. Therefore, the cybernetic bodies allow a new division of roles with no sex nor gender distinction.

In Woman on the Edge of Time, Piercy emphasizes that the eradication of sex and gender dualisms necessitatesthe blur of sexual distinctions through the abandonment of childbearing. In $\mathrm{He}$, She and It there is yet one more argument supporting that statement. Piercy presents the cyborg as an androgynous body who does not have any prejudice against women and expresses no aggressive or violent tendencies towards them. She substantiates the foregoing characterization by claiming that the reason for it is not being born of a female: "Of course, Yod has no prejudice against a woman because of age. He is not breaking any Oedipal taboos, for he was not born of woman. He was not born at all, and he does not sully his desire with fear of mistrust of women that way men raised by women do." ${ }^{34}$ Therefore, as Yod was not physically born, he does not go through the Freudian Oedipus complex and does not develop neither the desire towards women nor the rivalry towards other men. Moreover, the cyborg will obviously not find an identity with his father and consequently, will not acquire masculine characteristics. Hence, the cyborg which was not born of woman, does not experience the Freudian taboo of incest and does not develop either the complexes, or wariness toward women. The exactly same hypothesis is proposed by Haraway in her Cyborg Manifesto as she admits: "The cyborg is a creature in a postgender world; it has no truck with bisexuality, pre-oedipal symbiosis, unalienated labor, or other seductions to organic wholeness through a final appropriation of all the powers of the parts into a higher unity." 35 It is thus evident that Piercy provides yet another element supporting the postgender idea of technological alteration of childbearing. If one is not born of women, one does not develop the hatred or desire towards either of the parents. That consequently allows the subjects to stay neutral and this may be in fact the eminent foundation of a genderless world.

\footnotetext{
33 D. Haraway, op. cit., p. 174.

34 M. Piercy, He, She..., op. cit., p. 208.

35 D. Haraway, op. cit., p. 8.
} 
Let me argue that despite the metaphorical deconstruction of gender roles, Piercy introduces the androgynous cyborg for yet another reason - to represent the concept of social constructionism. While usually the introduction of cybernetic bodies is encountered as an element of the posthuman analysis of the relationship between humans and technology, this concept may also be used to question the gender system. Such an approach is visible for example in the novel Frankissstein (2019) by Jeanette Winterson, and it is also used in this case, by Marge Piercy. In $\mathrm{He}$, She and It she introduces the androgynous cyborg into the context of gender performativity in order to challenge the concept of gender.

The element of programming, which in many ways reflects the idea of constructionism, is a recurrent motif in the novel and is applied to both human and nonhuman beings. In several conversations between Yod and Shira, the element of programming reappears in such contexts that it may be understood as a kind of indoctrination. When Yod is wondering about the reason for some of his actions and preferences, Shira explains that it is merely his choice: "Yod, your programming creates your reactions. You didn't choose to enjoy it." ${ }^{36}$ While their conversation continues, the cyborg agrees but also admits that in this respect, they are no different: "You [Shira]'re programmed to like sweet tastes and avoid bitter ones. I'm programmed to find some things pleasurable and others painful. ${ }^{37}$ In this quite banal quote, we may find the metaphorical assumption that our preferences, dislikes, fears and pleasures are not choices made consciously, but rather choices that we are supposed to make as they seem normal and natural. The statement may be further supported in a later part of the novel where yet another conversation about behaviour and social actions appears. Yod points out: “Aren't you programmed too? Isn't that what socializing a child is?" 38 In a very straightforward manner, artificial programming is compared to the process of socialization, which brings to mind the assumption that humans, just like cyborgs, are programmed, that is raised in a particular manner as a reaction to social stimuli. Since in the novel the boundary between human and machine is blurred, the idea seems to have an even stronger impact. The freedom and individuality of the human being are put into question by the assumption that in the process of socialisation humans are in a way produced. A similar idea may be found in Halberstam, as in her analysis of gender she also makes the connection between gender and programming: "Gender, we might argue, like computer intelligence, is a learned, imitative behavior that can be processed so well that it comes to look natural. ${ }^{\prime 39}$ Here, the Butlerian theories of gender as performative acts are put into the context of cybernetic bodies as Halberstam points to the similarities between technological programming and the nature of gender constructions. The ideas mentioned by Halberstam can also be found in the novel when Yod questions the nature of his existence: "Does it feel almost as if I were human? Am I imitating behaviour I can never match?

\footnotetext{
${ }^{36}$ M. Piercy, He, She..., op. cit., p. 136.

37 Ibid.

${ }^{38}$ Ibid., p. 415.

39 J. Halberstam, op. cit., p. 443.
} 
(...) Am I pretending at something I'll always fail? ${ }^{40 "}$ As Yod tries to meet social expectations and to be what he is supposed to be, he gradually realises that he may always fail at being a human. The same claim may be applied to the concept of gender as some individuals are never capable of satisfying the expectations imposed by the social model, which attributes particular traits to males and females.

Similar ideas are incorporated by Haraway in her essay Cyborg Manifesto in which she not only proposes to break the boundaries between human and nonhuman, but also revises the concept of gender, rejecting the essentialist approach:

(...) gender cannot provide the basis for belief in "essential" unity. There is nothing about being "female" that naturally binds women. There is not even such a state as "being" female, itself a highly complex category constructed in contested sexual scientific discourses and other social practices. Gender is an achievement forced on us by the historical experience of the contradictory social realities of patriarchy. ${ }^{41}$

Haraway draws attention not only to the constructivist nature of gender, but also puts it into the context of a cybernetic body, which she acknowledges to be the perfect representation of non-essentialist models of culture. In Piercy we may encounter similar ideas. When Haraway compares human beings to cyborgs: “(...) we are all chimeras, theorized and fabricated hybrids of machine and organism - in short, cyborgs. The cyborg is our ontology; it gives us our politics;" "42 so does Piercy: "We are all cyborgs, Yod." ${ }^{43}$ The two statements bring to mind a metaphorical comparison of social programming which results in creating a particular, gendered human and in this respect human beings are no different from technologically constructed cybernetic bodies. Both authors seek to express the idea of hope and social regeneration in the postgender future where gender binarism ceases to exist. Utopian society is visibly based on gender transcendence and hope that social, cultural or biological roles of gender will be eradicated. Piercy finds the perfect harmonious utopia with genderless, androgynous societies or communities, and Haraway expresses the exact desire of the utopian world beyond gender: "We have all been injured, profoundly. We require regeneration, not rebirth, and the possibilities for our reconstitution include the utopian dream of the hope for a monstrous world without gender." 44

In both novels Piercy emphasizes the precariousness of her time and the fact that the future remains uncertain, by juxtaposing the potential utopian androgynous futures with alternative dystopian ones. Both Woman on the Edge of Time and $\mathrm{He}$, She and It present advanced, technological, totalitarian regimes ruled by corporate Multis. The two dystopian worlds share similar or almost the same ideas regarding the extension of sex and gender dichotomy. Those societies encourage rigid gender roles and stereotypes, which are fixed on the assumption that men and women are naturally predisposed to different tasks, responsibilities and abilities that are based not on their individual traits but on their sex. These

\footnotetext{
40 M. Piercy, He, She..., op. cit., p. 307.

${ }^{41}$ D. Haraway, op. cit., p. 16.

42 Ibid., p. 7.

43 M. Piercy, He, She..., op. cit., p. 193.

44 D. Haraway, op. cit., p. 67.
} 
assumptions are strongly ingrained in the heterosexual matrix, in which biological sex is the organic element determining one's gender, which in turn establishes sexuality. By creating such images, Piercy visibly links the undesirable dystopian representations with the concept of gender essentialism.

The two dystopian visions presented in the aforementioned novels present the societies in which such an essentialist approach is taken to the extreme. Both examples emphasize the subordinate position of women, who are treated as the possession of men in legal and social terms. In those worlds contracts are the foundation of the relationship between men and women; moreover, it is necessary for each woman to have such a settlement; otherwise she is not perceived as a citizen at all. The dystopian New York of Woman on the Edge of Time incorporates contracts which regulate the relation between man and woman, making it similar to prostitution: "All the flacks make contracts. Contract sex. It means you agree to put out for so long for so much. You know? Like I have a two-year contract. You can't get out of a contract unless you're bought out." ${ }^{45}$ Moreover, if a woman is not involved in such a relationship, she may be dismantled for organ banks. Y-S, however, is grounded on settlements called "marriages," which are usually provided for a period of five to ten years. Every woman who does not have a high, useful position in the city has to belong to a man; otherwise, she would have to leave the city of Y-S.

Sexual characteristics are intensified surgically, so that they take to the extreme the assumptions about masculine or feminine bodies. In Y-S: "Almost every exec, male or female, had been under the knife to resemble the Y-S ideal, faces as much like the one on the view screen as each could afford." ${ }^{46}$ It is, nevertheless, more important for females to match the ideal image of beauty: "a world of high glamour, surrounded by reconstructed females, bodies constantly resculpted by scalpels, implants, gels, to the last image of radiant beauty." ${ }^{, 47}$ In New York females were also surgically altered to conform to the ideal images of femininity with regard to the pleasure of men: "She seemed a cartoon of femininity, with a tiny waist, enormous sharp breasts that stuck out. Her stomach was flat but her hips and buttocks were oversized (...). Cosmetically fixed for sex use. Like you find in any knockshop." ${ }^{48}$ Furthermore, in future New York, while women serve only sexual roles, masculinity is taken to extremes as men are adapted to be aggressive professional killers. In Y-S, on the other hand, the ideal female has to prove herself to be feminine, possessing the particular psychological qualities, as females need to be: "girlish, shy, innocent, blithe"49 Piercy herself, in her description of Y-S, describes such vision as the one with "rigid sex roles."

The two novels provide the utopian dream of a world beyond gender where no one is limited or structured by any gender roles. The concept of androgyny pre-

\footnotetext{
${ }^{45}$ M. Piercy, Woman on the Edge..., op. cit., p. 318.

${ }^{46}$ Eadem, He, She..., op. cit., p. 6.

${ }^{47}$ Ibid.

${ }^{48}$ Eadem, Woman on the Edge..., op. cit., p. 314, 329.

${ }^{49}$ Eadem, He, She..., op. cit., p. 16.

${ }^{50}$ Ibid., p. 128.
} 
sented in the stories is portrayed as a balance in which traditional gender dichotomy is abandoned in favour of ambiguous androgynous bodies whose self-concept is based on general traits, referred to as universal human characteristics, rather than gender or sex attributes. For this reason, androgyny serves as a liberation from oppressive patriarchal structures that are in many ways ingrained in Heteromatrix and gender polarization. Both works are strongly weighted in favour of those images that are rooted in gender transcendence, in which gender binaries blur or cease to exist. Contrarily, the spheres where gender essentialism has been taken to an extreme reveal the threats of adhering to a gendered social model. By juxtaposing utopian and dystopian spaces, Piercy acknowledges both the possible hope for a progressive future beyond gender and the menaces of undesirable extension of rigid gender roles. Such a dream of postgender future is viewed as necessary for further social regeneration which incorporates annihilation of gender boundaries and liberation of full human potential. Hence, the androgynous balance may itself be perceived as hope for going towards equal, genderless society.

\section{References}

Annas P., New Worlds, New Words: Androgyny in Feminist Science Fiction, "Science Fiction Studies" 1978, 15.5/2, Jul., p. 143-156.

Attebery B., Decoding Gender in Science Fiction, New York 2002.

Butler J., Gender Trouble, New York 1990.

Dvorsky G., Hughes J., Postgenderism: Beyond the Gender Binary [in:] IEET Monograph Series, Boston 2008.

Firestone S., The Dialectic of Sex: The Case for Feminist Revolution, New York 1970.

Garnets L., Pleck J.H., Sex Role Identity, Androgyny, and Sex Role Transcendence, "Psychology of Women Quarterly" 1979, 3(3), p. 270-283.

Gelfand S., Shook J., Ectogenesis: Artificial Womb Technology and the Future of Human Reproduction, New York 2006.

Grosz E., Space, Time and Perversion: Essays on the Politics of Bodies, New York 1995.

Halberstam J., Female Masculinity, London 1998.

Haraway D., A Cyborg Manifesto: Science, Technology, and Socialist-Feminism in the Late Twentieth Century [in:] Simians, Cyborgs, and Women: The Reinvention of Nature, New York 1991, p. 149-181.

Hargreaves T., Androgyny in Modern Literature, New York 2005.

Jaggar A., Feminist Politics and Human Nature, Sussex 1983.

Johns A., Feminism and Utopianism [in:] The Cambridge Companion to Utopian Literature, ed. G. Claeys, Cambridge 2010, p. 174-199.

Lindsey L.L., The Sociology of Gender [in:] Gender Roles: A Sociological Perspective, Boston 2015, p. 1-21.

Piercy M., He, She and It, New York 1991.

Piercy M., Woman on the Edge of Time, New York 1976.

Teslenko T., Feminist Utopian Novels of the 1970s: Joanna Russ and Dorothy Bryant, New York 2003. 